kende bevolking ligt', zoals Catharina Lis het formuleerde in 'Proletarisch wonen in de Westeuropese steden in de igde eeuw: Van wildgroei naar sociale controle', BTNG 8 (I977) p. 337. Cor Smit beantwoordde deze vraagstelling in zes chronologisch afgebakende hoofdstukken: de periodes voor en na de Nederlandse Woningwet (I9OI), de periode van de Tweede Wereldoorlog, de Wederopbouwperiode, de jaren zestig tot tachtig van de twintigste eeuw en tot slot de periode van de eeuwwisseling van de twintigste naar de éénentwintigste eeuw. Voor elke periode brengt hij de evolutie van zowel de variabele vraag als de aanbodzijde in kaart. Hij heeft daarbij specifieke aandacht voor de rol van de diverse actoren: de woningbouwverenigingen als opdrachtgevers en investeerders en de bewoners en de overheid. Bovendien gaat Smit ook uitvoerig in op de evolutie die elk van deze actoren op zich ondergingen. De woningbouwverenigingen bijvoorbeeld, ontwikkelden zich in Leiden rond het einde van de negentiende als een vrijwilligersvereniging. Gegoede burgers namen zelf het initiatief in handen om kwalitatieve woningen te bouwen en zo ook de levenwijze van de (midden- en toplaag) van de arbeidersklassen te verbeteren. Het is pas na de Woningwet van I9OI dat ook de overheid een duidelijke rol toebedeeld kreeg. Tegelijk ontstaat ook het conflict tussen de professionele en bureaucratische controle op het ontwerpproces en uitvoeringsproces in de sociale woningbouw. Een onderwerp waar Nancy Stieber over geschreven heeft, zie haar Housing Design and Society in Amsterdam: Reconfiguring Urban Order and Identity, 1900-1920 (Chicago I998) 472.

$\mathrm{Na}$ de crisis van de Tweede Wereldoorlog werden de individuele woningbouwverenigingen gedwongen te fuseren. De woningnood was zowel kwantitatief als kwalitatief sterk toegenomen waardoor een structurele aanpak - inclusief degelijke financiële draagkracht en een professionele organisatiestructuur - onder streng toezicht van de overheid nodig was. Pas tegen het einde van de twintigste eeuw resulteert de door de woningbouwverenigingen als betuttelend en knellend ervaren relatie met de overheid in een verzelfstandiging van de woningbouwverenigingen. Het boek wordt afgesloten met een blik vooruit waarbij drie corporatiebestuurders en drie vertegenwoordigers van bewonersverenigingen reflecteren over de toekomst van de sociale huisvesting in hun regio. Het is de vraag waarom in dit laatste hoofdstuk de overheid - die nog steeds een cruciale rol speelt - niet aan bod komt.

Met Strijd om kwaliteit heeft Cor Smit zonder twijfel de verwachtingen van zijn opdrachtgever beantwoord. Maar het boek is meer dan dat. Het is een degelijk uitgewerkte micro-storia voor diegene die de Leidse situatie willen betrekken in een ruimere (inter-)nationale comparatieve studie over de geschiedenis van de volkshuisvesting.

Inge Bertels

Universiteit Antwerpen

Jeroen Koch, Abraham Kuyper. Een biografie (Amsterdam: Boom, 2006) 672 p. ISB N 9085062489

Op een biografie over Abraham Kuyper (I837-I920) werd lang gewacht. Sinds het proefschrift van P. Kasteel uit I938 was er geen samenvattende studie over deze belangrijke antirevolutionaire politicus meer verschenen. Waarom? Naast de geringe belangstelling voor het biografische genre zal de angst om zich te vertillen aan deze gigant een rol gespeeld hebben. Want Kuyper was van vele markten thuis. Hij stond aan de basis van de Gereformeerde Kerken in Nederland, de Antirevolutionaire Partij, en de Vrije 
Universiteit, was hoofdredacteur van het dagblad De Standaard en het kerkelijke weekblad De Heraut, en schreef tussendoor nog een halve (wetenschappelijke) bibliotheek vol. Daarbij drukte de charismatische Kuyper decennialang een stempel op de Nederlandse politiek. Dat wil niet zeggen dat er geen studie werd verricht naar Kuyper. Na de herdenking van zijn geboortedag in I987 was er zelfs sprake van een hausse aan (deel) studies. Vooral Jasper Vree droeg veel bij aan de kennis over de theoloog Kuyper. Op initiatief van het Abraham Kuyperfonds en met steun van Nwo schreef de Utrechtse historicus Jeroen Koch de langverwachte biografie. Het werd in de woorden van Koch een 'umerzählung' van wat bekend was; een synthese van het recente onderzoek.

Geheel in de stijl van de controversiële politicus werd de biografie met een relletje ontvangen. De gereformeerde historicus A.Th. van Deursen reageerde woedend in het Reformatorisch Dagblad. Hij noemde het een overbodig boek, waar noch waardig. Volgens hem was het geschreven in de taal van een 'libertijns pamflet - Nederlands met een Somalisch accent'. In de daaropvolgende discussie in de christelijke dagbladen ging de oud vu-hoogleraar nog verder door het een misselijk boek te noemen dat een fatsoenlijk mens niet wil lezen en een christen niet moet lezen. Het boek is inderdaad niet geschreven in de tale Kanaäns en voor christenen kan het storend zijn wanneer geloof als voorstellingswereld of als metafysica wordt geduid. Koch kiest echter consequent voor het perspectief van de buitenstaander. En het moet worden gezegd: de kritische distantie die hij hiermee schept is een verademing.

Met veel scepsis bekijkt Koch de beroemde bekering van Kuyper in de jaren zestig van de negentiende eeuw, toen Kuyper als dorpspredikant in het Betuwse Beesd werkte. De verschillende versies, van Kuyper zelf, verschillen nogal van elkaar. Koch ontleedt ze ragfijn en laat overtuigend zien hoe Kuyper ze zonder schroom benutte voor zijn politieke doeleinden. Tegen zijn politieke mentor en toenmalig leider van de antirevolutionairen, G. Groen van Prinsterer, was hij voorzichtig en terughoudend over zijn 'geloofscrisis'. Hij ontkende ooit in de ban geweest te zijn van de (onder invloed van de Verlichting staande) moderne theologie, zoals die gedoceerd werd in Leiden waar hij gestudeerd had. De intellectuele aanraking met onder andere een Poolse kerkhervormer had hem op het pad der rechtzinnigheid gebracht. Voor Kuypers achterban daarentegen kreeg de bekering dramatische en theatrale trekken. De 'vonk van God' die op hem was overgesprongen, maakte Kuyper tot een geroepene. Zijn wedergeboorte bewees dat hij door God uitgekozen was om zijn volk te verlossen uit achterstelling en onderdrukking. Zonder terughoudendheid bouwde hij aan zijn eigen legende. Hiermee schaarde Kuyper zich in de rij van het nieuwe type politicus dat aan het einde van de negentiende eeuw opkwam: de volksdemagogen die zich opwierpen als verlosser.

De aanleiding voor Kuypers deelname aan de kerkelijke, maatschappelijke en politieke strijd was de verdrukking waarin de religie terecht dreigde te komen. Geïnspireerd door paus Pius Ix, die de oorlog had verklaard aan de seculiere samenleving, ontvouwde hij een politiek-religieus program tegen het heersende liberalisme, ook, en aanvankelijk vooral, in de hervormde kerk ( $\mathrm{NHK}$ ). Dit program zou, ondanks vele latere aanpassingen, qua doelstelling in essentie niet meer veranderen. Koch omschrijft het als een activistisch neocalvinisme met een sterk antithetisch karakter. De herkerstening was het bindende element in Kuypers wereldbeeld. Centraal stond de kerk, van daaruit moest het gezin, de school en de staat hervormd worden. De negentiende-eeuwse scheiding tussen publiek en privé werd hiermee tot schrik van de liberalen opgeheven. Kuyper was geen conservatief, hij koos de aanval. Wie orthodox is kan geen conservatief zijn, zei Kuyper zelf; Koch typeert hem als revolutionair-religieus (p. 67). Bij de introductie van het kiesrecht in I867 binnen de N H K zag Kuyper de kans 
schoon de kerk naar orthodoxe beginselen te hervormen. Hij faalde en trad met een deel van de orthodoxen uiteindelijk uit de Nн к. Ook de herkerstening van de samenleving werd geen succes, zij strandde in een gereformeerde zuil.

Koch verklaart dit falen - ook nog een partijscheuring en een teleurstellend kabinet-Kuyper (I90I-I905) - uit Kuypers bezetenheid. De compromisloosheid, het niet kunnen rusten voordat de overwinning totaal is, riep tegenkrachten op die hem stopten. Gelijktijdig was deze bezetenheid de basis voor het grote werk dat Kuyper in zijn leven wist te verrichten. Koch is onder de indruk van de imposante figuur Kuyper die hij als 'systeembouwer' schaart in de rij van Marx, Hegel en Comte. Het is deze mengeling van bewondering en kritische analyse van Kuypers denk- en leefwereld die dit boek tot een genuanceerde biografie maken. Maar een vriend van Kuyper wordt Koch niet. Ondanks het boeiende portret dat hij van misschien wel de belangrijkste Nederlandse politicus van de laatste twee eeuwen schetst, blijft de afstand merkbaar. Dit komt onder andere tot uiting in het zoeken naar een psychologische basis van Kuypers wedergeboorte (p. 62-63). Op deze punten, Koch noemt hem nog manisch-depressief (p. 580), begeeft hij zich op het terrein waar de historicus niet thuis hoort.

Deze minpunten nemen niet weg dat Jeroen Koch een prachtige biografie over een fascinerende persoonlijkheid geschreven heeft, die, om op Van Deursen terug te komen, ieder fatsoenlijk mens wil lezen en elke christen zou moeten lezen.

\section{Arno Bornebroek}

Catelijne Akkermans, Aanspoelen aan de Achtergracht. Maatschappelijke ontwikkelingen, clientèlevorming en de psychiatrische patiënten van de Amsterdamse GG \& GD (1933-1988) (Amsterdam: Aksant, 2006) 230 p. Is в N 9052602158

'Ik behartig dit liever met de Zeereerwaarde Heer Pastoor en adviseurs die er geen Dossiers op na houden. Mijn man zei die kunnen ze tegen je gebruiken'; aan dat risico wilde zij haar gezin niet blootstellen (p. 29). Deze afwijzing van hulp is verwoord in een dossier uit I958 van de ambulante afdeling psychiatrie van de Amsterdamse GG\&GD aan de Achtergracht. Het is één van de patiëntendossiers waarover Catelijne Akkermans voor haar promotieonderzoek kon beschikken. Dat is een bijzondere bron want patiëntendossiers worden tegenwoordig uit privacyoverwegingen vernietigd. Aan de hand van deze psychiatrische ziektegeschiedenissen wilde Akkermans onderzoeken of en hoe de praktijk de theorieën bevestigde over de interactie tussen maatschappelijke ontwikkelingen en denkbeelden over psychiatrische zorg. De psychiatrische hulpverlening was een nieuw initiatief van de GG\&GD, gericht op Amsterdammers die dit niet zelf konden betalen of nergens anders terecht konden.

Psychiatrie heeft als historisch onderzoeksobject niet (meer) te klagen over een gebrek aan belangstelling. Voorafgegaan door gedenkboeken van psychiatrische inrichtingen die meer beschrijvend zijn, kwam er in de laatste twee decennia meer aandacht voor de maatschappelijke aspecten van die zorg. De ambulante psychiatrie was oorspronkelijk vooral het terrein van sociologisch theoretisch onderzoek. Inmiddels is daarover ook praktijkgericht onderzoek gepubliceerd, maar dossieronderzoek neemt daarin een marginale plaats in. Veel meer dan het onderzoek van De Swaan, Van Gelderen en Kense is er niet (zij maakten gebruik van spreekuur- en intakeverslagen van het Amsterdamse Instituut voor Medische Psychotherapie). En nu is er dus het onderzoek van Akkermans, socioloog en docent aan de Universiteit van Utrecht. 